\title{
The content of selected heavy metals and their bioavailable fraction in sediments of Solina Reservoir (Poland)
}

\author{
Dorota Piwińska ${ }^{1, *}$, and Renata Gruca-Rokosz ${ }^{1}$ \\ ${ }^{1}$ Department of Environmental Engineering and Chemistry, Rzeszow University of Technology, \\ Powstańców Warszawy 6, 35-959 Rzeszów, Poland
}

\begin{abstract}
Research on sediments of Solina Reservoir, Poland, were characterized by a content of copper higher than other heavy metals $(\mathrm{Cr}, \mathrm{Ni}, \mathrm{Cd}$ and $\mathrm{Zn})$. The strongest correlations between pairs of heavy metals were $\mathrm{Zn}-\mathrm{Cu}$ and $\mathrm{Ni}-\mathrm{Cr}$, were revealed while there was also a correlation between total contents of chromium and nickel, and between $\mathrm{pH}$ value and sediment percentage of organic matter. The content of copper at levels exceeding the geochemical background (more than 20-fold), sediments could only by classified as of the $3^{\text {rd }}$ purity class (according to the PIG criterion) or the $5^{\text {th }}$ purity class (according to Müller's classification). Ecotoxicological criteria indicate that levels of chromium, copper, nickel and cadmium are all high enough to affect aquatic life. However, the heavy metals analyzed differ in their mobility and bioavailability. The highest percentage value for the ion-exchangeable fraction was noted for cadmium, the lowest for chromium. This means that sediments have a greater capacity to release cadmium into the water column, with the consequence being secondary pollution source for the aquatic ecosystem.
\end{abstract}

\section{Introduction}

The contamination of reservoir sediments with heavy metals represents a major environmental problem due to potential negative impacts on the biological environment and - indirectly - on human health [1,2]. However, assessment of total contents of heavy metals in sediments do not suffice to assess environmental impact, given the presence in solid environmental samples in many forms and phases differing in mobility, bioavailability and toxicity. Mobility of a given element means the capacity for it, or one of its chemical forms, to move into the environment [3,4] in such a way as to pose a potential threat to living organisms. Heavy-metal mobility and bioavailability in sediment depends inter alia on chemical forms, the manner of binding to solid-phase components, and surface properties. Origin is also of relevance to form of occurrence, given various potential combinations of mineral or organic components in soils, dusts, ashes, sediments and sewage sludge [5].

\footnotetext{
* Corresponding author: d.piwinska@.prz.edu.pl
} 
Chemical fractionation is used commonly to predict the preservation of heavy metals in solid samples, with separate fractions obtained using solutions of increasing leaching strength. The most mobile and bioavailable fraction is the ion-exchangeable fraction, which includes heavy metals adsorbed ion-exchangeably on a surface in the solid phase. Such metal ions only retained by weak electrostatic bonds can be released into the water column readily. For example, in the environmental conditions such releases of heavy metals may result from increased salinity, a change in concentration of complexing agents or a lowering of $\mathrm{pH}[6]$.

In the work the above methodology was used to determine the contents of selected heavy metals. The aim of the paper was to assess the level of contamination in sediments of Poland's Solina Reservoir. To assess bioavailability, reference was made to single extractions isolating ion-exchangeable fractions of heavy metals.

\section{Materials and methods}

The studied sediments are those of Solina Reservoir, which is Poland's largest in volume terms. Sampling was carried out a single time in July 2016, using a gravity sampler (KC Kajak). The locations of the 6 sampling stations are shown in Fig. 1, with morphometric parameters of the Reservoir also presented. Sampling stations were chosen close to the water dam (1), in Jawor (2), in Werlas (3), in Polańczyk (4) and near the Reservoir tributaries: San and Czarny river (5) and Solinka River (6).

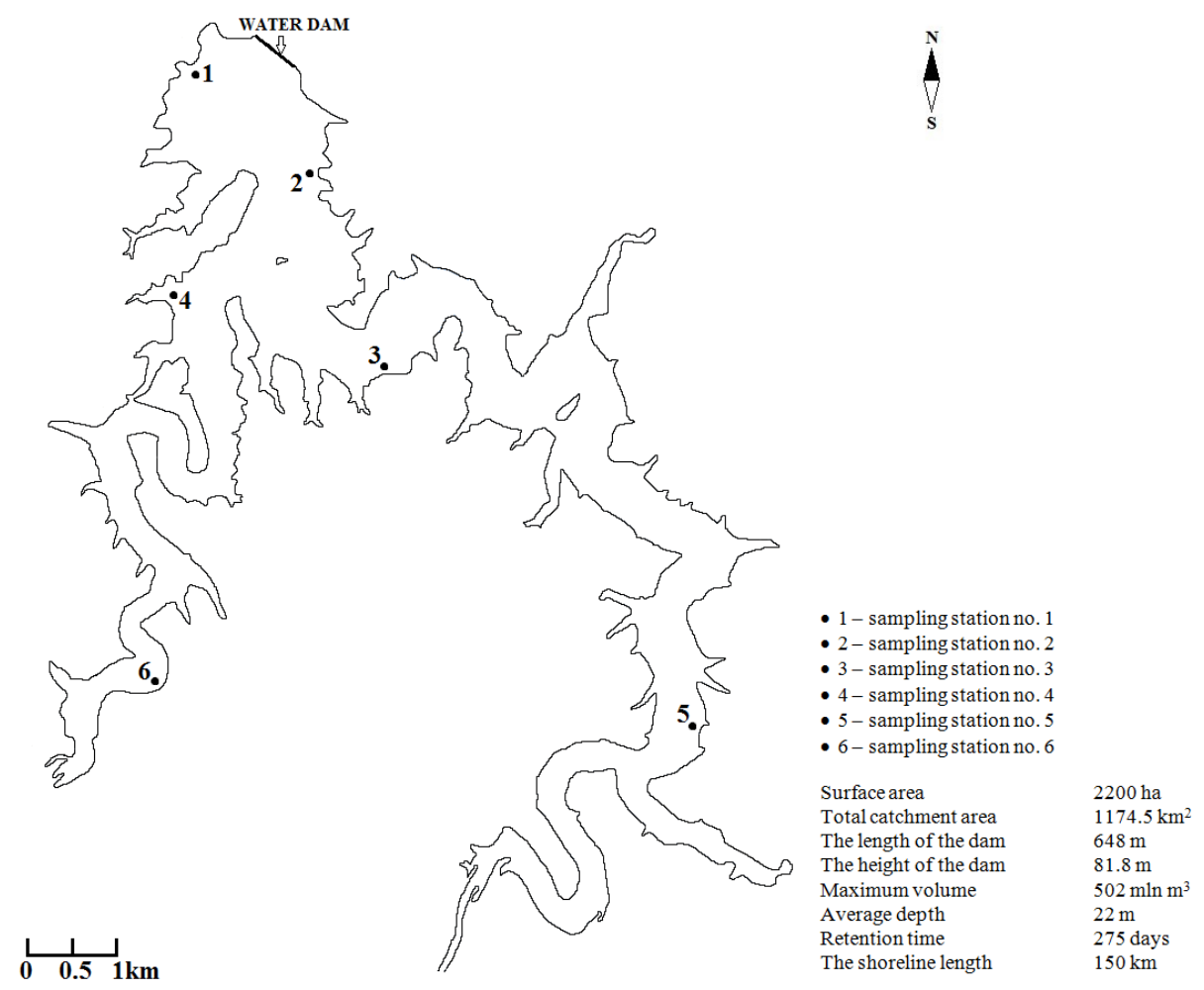

Fig. 1. Solina Reservoir - location of sampling stations and morphometric parameters. 
Sampling for analysis was confined to the uppermost $5 \mathrm{~cm}$ of sediments, which were then dried to constant weight at room temperature, and then at $60^{\circ} \mathrm{C}$. The sediments were milled, prior to determinations being made for such parameters as: $\mathrm{pH}$, percentage of organic matter $(\mathrm{OM})$, organic carbon (TOC), total nitrogen $(\mathrm{TN})$, carbonates $\left(\mathrm{CO}_{3}{ }^{2-}\right)$, as well as metals, including heavy metals $\mathrm{Al}, \mathrm{Fe}, \mathrm{Cr}, \mathrm{Cu}, \mathrm{Ni}, \mathrm{Cd}, \mathrm{Zn}$. Ion-exchangeable fractions within total contents were determined for $\mathrm{Cr}, \mathrm{Cu}, \mathrm{Ni}, \mathrm{Cd}$ and $\mathrm{Zn}$.

$\mathrm{OM}$ content was determined as loss after drying of sediments within $4 \mathrm{~h}$ at $550^{\circ} \mathrm{C}$. Reaction was determined potentiometrically (MultiLine P4, WTW, Germany) in slurry with $1 \mathrm{~N} \mathrm{KCl} \mathrm{[7].} \mathrm{Carbonate} \mathrm{content} \mathrm{was} \mathrm{measured} \mathrm{by} \mathrm{volume} \mathrm{using} \mathrm{the} \mathrm{Scheibler} \mathrm{apparatus,}$ while TOC and $\mathrm{TN}$ contents were determined at $1020^{\circ} \mathrm{C}$ using a $\mathrm{CN}$ elemental analyzer (Flash EA 1112, ThermoQuest). Prior to determination of TOC content, the dried and ground sediment samples were placed in a desiccator with concentrated $\mathrm{HCl}$ vapors [8] for $24 \mathrm{~h}$, to ensure the removal of carbonates. Prior to analysis, the sediment sample was again dried to constant weight at $60^{\circ} \mathrm{C}$.

To mineralize sediments in order to determine total contents of some heavy metals, portions weighing about $0.5 \mathrm{~g}$ were placed into a Teflon vessel and $10 \mathrm{ml}$ of concentrated, spectrally pure nitric acid was then added. Samples were placed into a MARS 6 Microwave Digestion System, and mineralized using microwave energy at 1600 watts for $40 \mathrm{~min}$. at $180^{\circ} \mathrm{C}$ (temperature rise time -15 minutes, soaking time -25 minutes). After cooling, mineralizates were filtered through quantitative paper filters, and additionally using syringe filters. Heavy metal contents were then determined using a plasma emission spectrometer (ICP-OES GBC Quantima E 1330).

To determine the bioavailable fraction of certain heavy metals, $6 \mathrm{~g}$ portions of sediment were shaken with $60 \mathrm{ml}$ of 0.01 mole $\mathrm{CaCl}_{2}$ at room temperature for $2 \mathrm{~h}$ [9]. The samples were then centrifuged and filtered through syringe filters. They were analyzed for heavy metal content by the method described above.

Contamination of sediments with the heavy metals analyzed was assessed by reference to the classification from the Polish Geological Institute [1], Müller's classification [10] and ecotoxicological criteria $[11,12]$.

\section{Results and discussion}

Results for certain chemical parameters of Solina Reservoir sediments are presented in Table 1.

Table 1. Chemical content and selected parameters in the sediments analyzed.

\begin{tabular}{|c|c|c|c|c|c|c|c|}
\hline \multirow{2}{*}{ Parameter } & \multirow{2}{*}{ Unit } & \multicolumn{6}{|c|}{ Station } \\
\hline & & 1 & 2 & 3 & 4 & 5 & 6 \\
\hline $\mathrm{pH}$ & - & 8.03 & 8.09 & 7.72 & 8.02 & 7.96 & 8.01 \\
\hline $\mathrm{CO}_{3}{ }^{2-}$ & \multirow{4}{*}{$\%$} & 6.28 & 5.91 & 0.33 & 1.2 & 1.29 & 1.57 \\
\hline $\mathrm{OM}$ & & 2.80 & 1.23 & 4.86 & 1.40 & 1.66 & 1.73 \\
\hline TOC & & 0.80 & 0.37 & 0.96 & 0.33 & 0.31 & 0.52 \\
\hline $\mathrm{TN}$ & & 0.046 & 0.036 & 0.080 & 0.016 & 0.033 & 0.022 \\
\hline $\mathrm{C}: \mathrm{N}$ & - & 18 & 10 & 12 & 20 & 9 & 23 \\
\hline $\mathrm{Fe}$ & \multirow{2}{*}{$\%$} & 1.27 & 0.88 & 1.81 & 1.22 & 1.38 & 1.12 \\
\hline $\mathrm{Al}$ & & 1.14 & 0.92 & 1.86 & 0.96 & 1.52 & 0.94 \\
\hline
\end{tabular}


Sediments from all the sampling stations were slightly alkaline, with $\mathrm{pH}$ values in the 7.72-8.09 range. The lowest value characterized sediments at Station 3, the highest those at Station 2. Contents of carbonate were low, ranging from $0.33 \%$ at Station 3 to $6.28 \%$ at Station 1. Comparable values for carbonate content (3.47-7.56\%) have been obtained for sediments of Rzeszów Reservoir [unpublished materials], while Besko Reservoir reports higher values in the range 6.12-13.23\%) [13]. In turn, Dobczyce Reservoir sediments are found to have a still-more-limited abundance of carbonate, in the $0.42-3.18 \%$ range [14].

The sediments of Solina Reservoir are also low in organic matter, with contents ranging from $1.23 \%$ at Station 2 to $4.86 \%$ at Station 3. Organic carbon content (TOC) was found to correlate strongly with $\mathrm{OM}$ content $\left(\mathrm{R}^{2}=0.86\right)$. Sediments were also characterized by a low total nitrogen (TN) content - in the range $0.016 \%$ (Station 4 ) to $0.080 \%$ (Station $3)$. Positive correlations were obtained between OM and TN content $\left(\mathrm{R}^{2}=0.87\right)$ as well as between TOC and TN $\left(\mathrm{R}^{2}=0.71\right)$. For comparison, Besko Reservoir was previously found to have $\mathrm{OM}$ in sediments in the $3.88-5.93 \%$ range [13], and Rzeszów Reservoir 4.83-9.22\% [unpublished materials]. Higher TOC values were also noted, i.e. $1.11-1.81 \%$ (Besko) [13] and 1.35-2.58\% (Rzeszów) [unpublished materials]. Furthermore, sediments of Włocławek Reservoir have an OM content over twice as high - at 11.5\% [15].

$\mathrm{C}: \mathrm{N}$ ratios in the sediments of Solina Reservoir range from 9 to 23. The such highest ratio characterizes Station 6, and the lowest Station 5. Values for the C:N ratio indicate that organic matter (OM) (especially at Stations further along from the dam) is supplied mainly from the catchment area. In turn, lower $\mathrm{C}: \mathrm{N}$ values at Stations close to the dam indicate a greater share of autochthonous matter in sediments.

Solina Reservoir sediments were characterized by iron contents in the range $0.88-1.81 \%$ and by aluminum in the range $0.92-1.86 \%$. The sediment contents of these heavy metals are lowest at Station 2, while the peak values noted for aluminum and iron are at Station 3. These values were similar to those obtained in sediments of Besko Reservoir (Fe: 1.88 2.23\%, Al: 1.34-1.85\%) [13] and Rzeszów Reservoir (Fe: 1.24-1.87\%, Al: 1.31-2.48\%) [unpublished materials].

The sediments of Solina Reservoir were also analyzed for their contents of the heavy metals $\mathrm{Cr}, \mathrm{Cu}, \mathrm{Ni}, \mathrm{Cd}$ and $\mathrm{Zn}$. The results of this analysis are presented in Fig. 2.

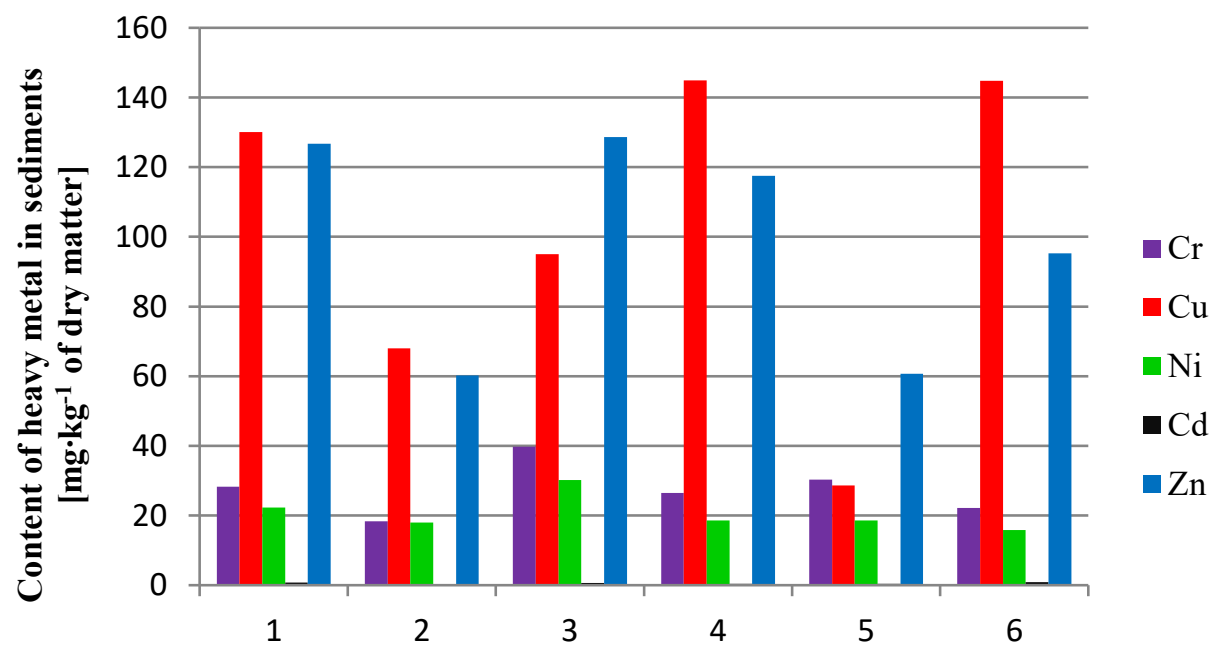

Sampling station

Fig. 2. Contents of heavy metals in sediments of Solina Reservoir. 
Sediments of Solina Reservoir are characterized by significant contamination by heavy metals, such as copper (28.68-144.85 $\mathrm{mg} \cdot \mathrm{kg}^{-1}$ of dry matter) and zinc $(60.16-128.62$ $\mathrm{mg} \cdot \mathrm{kg}^{-1}$ of dry matter). In terms of total content, these elements were clearly predominant over the other heavy metals. A similar content of zinc was present in sediments of Rzeszów Reservoir (73.35-118.06 mg $\mathrm{kg}^{-1}$ of dry matter) [unpublished materials], while lower values were recorded in sediments of Zesławice Reservoir (55.0-72.6 mg $\mathrm{kg}^{-1}$ of dry matter) [16] and Krempna Reservoir (39.7-79.5 mg $\mathrm{kg}^{-1}$ of dry matter) [16]. In turn, copper concentrations may indicate moderate sediment contamination in comparison with other reservoirs. For example, copper was present in the sediments of Zesławice Reservoir at contents of 5.1-7.7 $\mathrm{mg} \cdot \mathrm{kg}^{-1}$ of dry matter [16], with Włocławek Reservoir reporting $55.8 \mathrm{mg} \cdot \mathrm{kg}^{-1}$ of dry matter [17], and Rybnik Reservoir having a far higher sediment content of $1000.0 \mathrm{mg} \cdot \mathrm{kg}^{-1}$ of dry matter [16].

The highest values for $\mathrm{R}^{2}$ determination coefficients concern the $\mathrm{Zn}-\mathrm{Cu}$ relationship (0.52) and that between $\mathrm{Ni}$ and $\mathrm{Cr}(0.75)$. High correlations between total contents of different heavy metals have also been confirmed by other authors [18; 19].

There was also a clear relationship between total contents of chromium and nickel, and the $\mathrm{pH}$ value $(\mathrm{pH}-\mathrm{Cr}: 0.84, \mathrm{pH}-\mathrm{Ni}: 0.74)$, as well as the percentage of organic matter in sediments (OM-Cr: 0.74, OM-Ni: 0.92). Such results are confirmed in certain other publications $[20,21]$.

In line with the classification of river and lake sediments prepared by the Polish Geological Institute (PIG), sediments of Solina Reservoir can be categorized as of purity class 3 (heavily contaminated), mainly on account of the highest (more than 20-fold) exceedances of the geochemical background value for copper. In turn, the application of Müller's criterion confirmed the $5^{\text {th }}$ purity class (i.e. strongly to extremely contaminated sediments), with this again confirmed by observed values for the geoaccumulation index in respect of copper $\left(4<\mathrm{I}_{\text {geo }}<5\right)$. Finally, where ecotoxicological criteria are taken into account levels of chromium, copper, nickel and cadmium may all be regarded as potentially toxic to living organisms ( $>$ LEL, TEL). Possible toxic effects due to zinc are not anticipated, however (<PEL; no TEL).

Analysis related to overall contents of heavy metals was augmented by considerations of their mobile fractions. The results are as shown in Fig. 3.

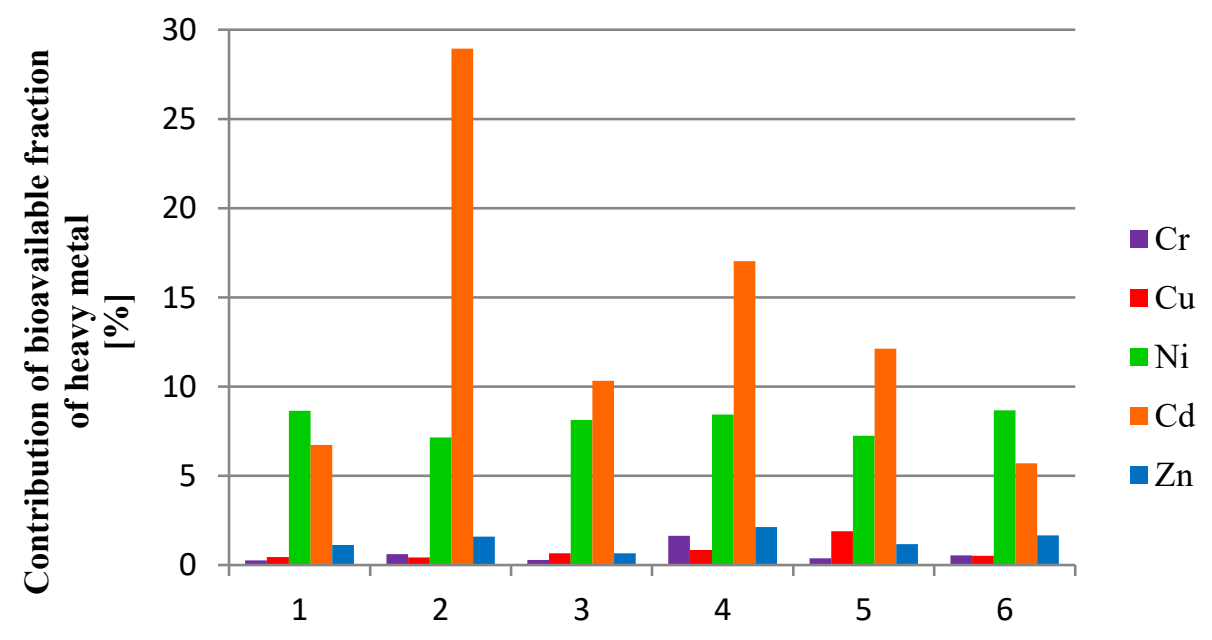

Sampling station

Fig. 3. Bioavailable fractions of heavy metals in sediments of Solina Reservoir. 
The procedure by which the mobile fraction was extracted yielded the following hierarchy for the mobility of heavy metals (and hence for the possibility of secondary water contamination in a reservoir): $\mathrm{Cd}>\mathrm{Ni}>\mathrm{Zn}>\mathrm{Cu}>\mathrm{Cr}$. This order reflects percentage amounts of heavy metals in the ion-exchangeable fraction. This fraction is considered the most mobile and the most sensitive to changes in environmental condition in the benthic zone. Where quantified $\mathrm{mg} \cdot \mathrm{kg}^{-1}$ contents of the heavy metals are concerned, the ordering is: $\mathrm{Cu}>\mathrm{Zn}>\mathrm{Cr}>\mathrm{Ni}>\mathrm{Cd}$.

As is clear from the above, the ion-exchangeable fraction is largest percentagewise in the case of cadmium (in the range 5.71-28.94\%), notwithstanding the content lower than for any of the other heavy metals. Sediments of Rzeszów and Mokre Ląki Reservoirs, as well as the River Utrata and Łasica Canal have also been characterized by high cadmium mobility in previous work (Table 2).

Table 2. Share of the mobile fraction of some heavy metals in sediments of selected aquatic ecosystems.

\begin{tabular}{|c|c|c|c|c|c|c|c|}
\hline & \multirow{2}{*}{ Name } & \multirow{2}{*}{$\begin{array}{c}\text { Aquatic } \\
\text { ecosystem }\end{array}$} & \multicolumn{6}{|c|}{ Max. contribution of the bioavailable fraction } & \multirow{2}{*}{ Reference } \\
\cline { 3 - 7 } & & $\mathrm{Cr}$ & $\mathrm{Cu}$ & $\mathrm{Ni}$ & $\mathrm{Cd}$ & $\mathrm{Zn}$ & \\
\hline Solina & Reservoir & 1.64 & 1.90 & 8.66 & 28.94 & 2.13 & [our study] \\
\hline Rzeszów & Reservoir & 0.47 & 2.38 & 20.46 & 11.54 & 1.09 & $\begin{array}{c}\text { [unpublished } \\
\text { materials] }\end{array}$ \\
\hline $\begin{array}{c}\text { Mokre } \\
\text { Łąki }\end{array}$ & Reservoir & $\sim 12.00$ & $\sim 4.00$ & - & $\sim 20.00$ & $\sim 10.00$ & {$[2]$} \\
\hline Utrata & River & - & 0.30 & - & 47.00 & 3.00 & {$[22]$} \\
\hline $\begin{array}{c}\text { Lasica } \\
\text { Canal }\end{array}$ & River & $\sim 3.00$ & $\sim 6.00$ & - & $\sim 20.00$ & $\sim 2.00$ & {$[2]$} \\
\hline Liwiec & River & - & 12.80 & 15.60 & - & 13.70 & {$[23]$} \\
\hline
\end{tabular}

The ion-exchangeable fractions within the total contents of chromium, copper and zinc are found to be similar to those in the sediments of Rzeszów Reservoir $(\mathrm{Cr}, \mathrm{Cu}, \mathrm{Zn})$, the Łasica Canal (Cr, Zn) and the River Utrata $(\mathrm{Cu}, \mathrm{Zn})$. However, Solina Reservoir sediments appear to feature only limited bioavailability of nickel - when compared with Rzeszów Reservoir and the River Liwiec, for example.

Clearly, precise comparisons with results for other water bodies are not entirely possible due to varying methods and extractants used. Most previous research [2, 22, 23] has applied extractants other than the $\mathrm{CaCl}_{2}$ used in our work.

\section{Conclusions}

Analysis of sediments from Poland's Solina Reservoir in terms of their heavy-metal contamination and assessed potential toxicity to living organisms yields conclusions as follows:

- Compared with other heavy metals studied, it was copper that achieved highest values (28.68-144.85 $\mathrm{mg} \cdot \mathrm{kg}^{-1}$ of dry matter), with these found to exceed geochemical background levels more than 20 -fold.

- The Reservoir tributary (Solinka River) carries a lot of pollutants, mainly heavy metals such as $\mathrm{Cu}$ and $\mathrm{Zn}$ which can be released from industrial effluents, agricultural return flows and domestic sewage. Significant correlations 
between the measured concentrations of heavy metals and locations of other sampling stations were not observed.

- The individual heavy metals whose contents correlated with each other most closely were $\mathrm{Zn}$ and $\mathrm{Cu}\left(\mathrm{R}^{2}=0.52\right)$ and $\mathrm{Ni}$ and $\mathrm{Cr}\left(\mathrm{R}^{2}=0.75\right)$.

- Also correlated were total contents of chromium and nickel as set against either $\mathrm{pH}$ value ( $\mathrm{pH}-\mathrm{Cr}$ : $0.84, \mathrm{pH}-\mathrm{Ni}: 0.73$ ) or percentage organic matter in sediments (OM-Cr: 0.74, OM-Ni: 0.92).

- In line with criteria from the Polish Geological Institute (PIG), sediments at Solina only achieve purity class 3 , indicative of heavy contamination. Where Müller's classification is applied, sediments are found to be in the $5^{\text {th }}$ purity class (denoting strong to extreme contamination). Ecotoxicity criteria in turn suggest contents of chromium, copper, nickel and cadmium potentially toxic to living organisms.

- Mobility data for the heavy metals yield a hierarchy $\mathrm{Cd}>\mathrm{Ni}>\mathrm{Zn}>\mathrm{Cu}>\mathrm{Cr}$, with cadmium more mobile than any other heavy metal studied. This element thus has a greater capacity for release from sediment into the water column and causing secondary contamination. The high mobility of cadmium is confirmed in other studies.

- While results for heavy-metal bioavailability in Solina Reservoir have been compared loosely with those for other aquatic ecosystems, this comparison is limited by differences in research procedures applied.

The paper was financed by National Science Centre Poland, via grant no. 2017/25/B/ST10/00981.

\section{References}

1. I. Bojakowska, G. Sokołowska, Prz. Geol., 46, 49-54 (1998)

2. J. Pawłowski, M. Rozental, A. Drzewińska, S. Neffe, Biuletyn WAT, 4, 113-134 (2014)

3. J. Gawdzik, Gaz, woda i technika sanitarna, 5, 33-36 (2010)

4. R. Gruca-Rokosz, L. Bartoszek, J.A. Tomaszek, Env. Prot. Eng., 30, 45-50 (2004)

5. L. Bartoszek, P. Koszelnik, R. Gruca-Rokosz, M. Kida, Rocz. Ochr. Śr., 17, 396-409 (2015)

6. R. Świetlik, M. Trojanowska, Monitoring Środ. Przyr., 10, 35-44 (2009)

7. A. Ostrowska, S. Gawliński, Z. Szczubiałka, IOŚ (1991)

8. C.F. Zimmermann, C.W. Keefe, J. Bashe, NER Laboratory, USEPA (1997)

9. V.J.G. Houba, I. Novozamsky, T.M. Lexmind, J.J. van der Lee, Commun. Soil Sci. Plant Anal., 21, 19-20 (1990)

10. G. Müller, Chemiker-Zeitung, 6, 157-164 (1981)

11. D. Persaud, R. Jaagumagi, A. Hayton, Ontario Ministry of the Environment, 1-39 (1993)

12. D.D. MacDonald, C.G. Ingersoll, T.A. Berger, Arch. Environ. Contam. Toxicol., 39, 20-31 (2000)

13. D. Piwińska, R. Gruca-Rokosz, L. Bartoszek, J.Czarnota, J. Environ. Eng., 19, 104-112 (2018)

14. D. Wójcik, Ochr. Śr., 42, 31-34 (1991)

15. J. Trojanowska, J. Antonowicz, Słupskie Pr. Biol., 2, 123-127 (2005)

16. M. Madeyski, M. Tarnawski, IETW, 4, 107-116 (2006)

17. P. Gierszewski, Landform Analysis, 9, 79-82 (2008)

18. G. Głosińska, T. Sobczyński, L. Boszke, K. Bierła, J. Siepak, Pol. J. Environ. Stud., 14, 305-317 (2005) 
19. K. Rozpondek, R. Rozpondek, P. Pachura, Acta Sci. Pol. Formatio Circumiectus, 16, 33-43 (2017)

20. Cz. Jasiewicz, A. Baran, J. Elementol., 11, 307-317 (2006)

21. R. Rozpondek, K. Wancisiewicz, Inżynieria i Ochrona Środowiska, 19, 37-49 (2016)

22. M. Wojtkowska, J. Bogucki, Ochr. Śr., 34, 43-46 (2012)

23. K. Pakuła, D. Jaremko, M. Becher, Proc. ECOpole, 6, 641-646 (2012) 